\title{
Pentingnya Materi Lingkungan dalam Pembelajaran Bahasa Indonesia
}

Lingkungan merupakan bagian penting dalam kehidupan manusia karena, pada kehidupannya manusia menempati lingkungan sebagai tempat untuk bertahan hidup dan melakukan berbagai macam aktivitas. Lingkungan juga menjadi tempat perkembangan kehidupan manusia. Lingkunganlah yang mempengaruhi baik atau buruknya perilaku manusia. Hal ini dikarenakan pengaruh lingkungan yang sangat besar pada kehidupannya. Namun, pada lingkungan sering kita temui berbagai masalah. Menurut Tung dan Wihardjo (dalam Ramadhan et al, 2019), masalah yang terjadi di lingkungan disebabkan oleh aktivitas manusia yang ceroboh dan intensif di daerah tempat ia tinggal, hal ini dilakukan untuk meningkatkan kualitas hidupnya masing-masing. Banyak dari manusia tidak memikirkan lingkungan ketika melakukan hal-hal yang dapat merusak lingkungan. Kebanyakkan dari mereka hanya memikirkan diri sendiri dan tidak memikirkan dampak apapun yang akan terjadi dari perbuatannya tersebut. Dampak dari perbuatannya seperti, membuang sampah sembarangan akan mengakibatkan lingkungan tercemar dan terjadinya banjir. Hal ini dikarenakan sikap egois yang ada pada diri manusia. Menurut Erdogan, Wang J, dan Uyar Y (dalam Ramdhan et al, 2019), diperlukan individu yang sadar dan bertanggungjawab terhadap lingkungan agar dapat mengatasi masalah ini. Sehingga lingkungan dapat membaik dan begitu juga dengan kualitas kehidupan. Hal tersebut dapat capai dengan menghubungkan lingkungan dengan bidang ilmu lain seperti bidang pendidikan yang lebih dikhususkan pada pendidikan lingkungan.

Menurut Nkwetisma (dalam Ramadhan et al, 2019), pendidikan lingkungan merupakan suatu usaha yang dilakukan secara sadar untuk mengajar dan menarik perhatian manusia tentang bagaimana fungsi lingkungan alam dan bagaimana manusia ini dapat mengelola dan melindunginya. Menurut Lai dan Buldur (dalam Ramadhan et al, 2019), pendidikan lingkungan dapat diaplikasikan dalam proses pembelajaran langsung di kelas. Pada pembelajaran bahasa Indonesia dapat menghubungkan materi tentang lingkungan dengan materi-materi yang diajarkan. Berdasarkan penelitian penulis $55,8 \%$ responden setuju dan $44,2 \%$ sangat setuju bahwa materi tentang lingkungan wajib dikaitan dengan pembelajaran bahasa Indonesia sejak tingkat SLTP untuk menjadikan siswa peduli lingkungan sejak dini. Responden berasal dari kalangan guru, siswa dan mahasiswa diberbagai universitas. Manusia seharusnya lebih peduli dengan lingkungan sekitar. Sebanyak 37,2\% responden sangat setuju dan $60,5 \%$ setuju bahwa materi lingkungan dalam kurikulum 2013 dapat menjadikan siswa lebih peduli dengan lingkungan sekitar dan 2,3\% responden memiliki jawaban kurang setuju terhadap hal tersebut. Dalam pembelajaran bahasa Indonesia dapat menghubungkan topik yang ada dengan lingkungan. Sebanyak $27,9 \%$ responden kurang setuju, 55,8\% setuju dan $16,3 \%$ sangat setuju bahwa setiap topik yang ada dalam pembelajaran bahasa Indonesia harus dikaitkan dengan materi lingkungan. Sebanyak 2,3\% responden tidak setuju, 16,3\% kurang setuju, 60,5\% setuju, dan 20,9\% sangat setuju bahwa tidak semua topik yang ada dipembelajaran bahasa Indonesia dapat dikaitakan dengan materi lingkungan. Selain itu dalam mengaitkan materi lingkungan dengan pembelajaran bahasa Indonesia juga dapat dilakukan dengan cara membuat teks, 11,6\% responden kurang setuju, 69,8\% setuju dan $11,6 \%$ sangat setuju apabila siswa diintrusikan membuat teks tentang lingkungan berdasarkan teks yang sedang dipelajarinya. 7\% responden kurang setuju, 74,4\% setuju, dan 28,6\% sangat setuju bahwa materi yang ada pada kurikulum 2013 memuat topik tentang peran masyarakat terhadap lingkungan. Pada pernyataan materi tentang lingkungan yang ada pada pembelajaran bahasa Indonesia dapat menumbuhkan rasa 
ingin tahu siswa tentang cara menjaga lingkungan yang baik 9,3\% responden kurang setuju, $60,5 \%$ setuju dan 30,2\% sangat setuju. Guru juga memiliki peran penting dalam pengajaran materi lingkungan dalam pembejalaran bahasa Indonesia. 18,6\% responden kurang setuju, 55,8\% setuju dan 25,6\% sangat setuju bahwa guru telah memberikan contoh nyata kepada siswa mengenai pentingnya menjaga lingkungan. Kesadaran pada diri seseorang terhadap pentingnya menjaga lingkungan akan membuat lingkungan membaik. 4,6\% responden kurang setuju, 60,5\% setuju dan $34,9 \%$ sangat setuju bahwa materi lingkungan dalam pembelajaran bahasa Indonesia dapat menumbuhkan kesadaran siswa terhadap buruknya dampak tidak menjaga lingkungan. 69,8\% responden setuju dan 30,2\% sangat setuju bahwa materi lingkungan yang ada pada pada kurikulum 2013 dapat meningkatkan pengetahuan siswa tentang lingkungan sekitarnya.

Berdasarkan hasil penelitian yang telah dilakukan oleh penulis, dapat disimpulkan bahwa pendidikan memiliki peran yang penting untuk menumbuhkan kesadaran siswa terhadap perlunya menjaga lingkungan. Pendidikan lingkungan dapat dimasukkan kedalam pembelajaran langsung bahasa Indonesia. Siswa dapat diintruksikan untuk membuat teks yang sedang dipelajari dengan bertemakan lingkungan. Penulis berharap dengan adanya menerapan pendidikan lingkungan yang ada pada pembelajaran bahasa Indonesia dapat menjadikan lingkungan menjadi lebih baik untuk kedepannya. Sama-sama kita ketahui bahwa lingkungan sangat memiliki peran penting bagi kehidupan.

\section{DAFTAR KEPUSTAKAAN}

Buldur A and Ömeroglu E. (2018). An examination of the relationship between pre-school children's and their teacher' attitute and awareness towards the environment Journal of Education and Learning 7(2) 221-9

Erdogan M. (2015). The effect of summer environmental education program (SEEP) on elementary school students' environmental literacy International J. Sci. Env. Ed. 10(2) 165-181

Lai C S.(2018). A study of fifth graders' environmental learning outcomes in Taipei International Journal of Research in Education and Science 4(1) 252-61

Nkwetisma C M. (2011). EFL/ESL and environmental education: towards an eco-applied linguistic awareness in Cameroon World Journal of Education 1(1) $110-18$

Ramadhan, S., Sukma, E., \& Indriyani, V. (2019). Environmental education and disaster mitigation through language learning. IOP Conference Series: Earth and Environmental Science, 314.

Tung C Y, Huang C C and Kawata C. (2002) The effects of different environmental education programs on the environmental behaviors of 8th grade students and related factors Journal of Environmental Health 64(7) 24-9

Uyar Y and Ensar F. (2016). Does mother tongue education support development of environmental literacy in Turkey? An analysis of Turkish course book International Journal of Environmental \& Science Education 11(1) 1-8 
Wihardjo S D, Hartati S, Nurani Y and Sujarwanta A. (2017). The effects of green schooling knowledge level and intensity of parental guidance on the environmental awareness of the early age student Educational Research and Reviews 12(5) 251-57

Wang J, Zhu M, Tang X, He M, Xu S, Gao Y and Gu J. (2010) Opportunities and challenges for environmental education at yunnan's institutions of higher learning Chinese Education \& Society 43(2) 82-93 